\title{
A New Era for CNS Spectrums
}

\author{
By Andrew A. Nierenberg, MD
}

CNS Spectrums provides a unique international forum for psychiatry, neurology, and neuropsychiatry that spans the full spectrum of brain diseases and gives practical evidence to enhance clinical knowledge and inform clinical practice. In 2008, articles published in CNS Spectrums have covered the spectrum from attention-deficit/hyperactivity disorder to the subgenual anterior cingulated cortex. Founding Editor Eric Hollander, MD, steered CNS Spectrums to fill the specific niche of neuropsychiatry and its vicissitudes. We owe him thanks for his vision, energy, and devotion in making CNS Spectrums a successful journal.

As the founding publisher of MBL Communications, Inc., Darren L. Brodeur has had the vision to produce an international journal that disseminates information that will ultimately help patients. Joseph Zohar, MD, as the international editor and Donatella Marazziti, MD, Dan J. Stein, MD, PhD, and Shigato Yamawaki, $M D, P h D$, as the associate editors have provided a full spectrum of international expertise. Dr. Stein and Stephen M. Stahl, MD, PhD, have provided regular columns that integrate multiple aspects of brain and psychiatry. CNS Spectrums' reviews have synthesized the neuropsychiatric relationships between psychiatric disorders and neuroscience and between neurological disorders and psychiatry.
The editorial advisory board has contributed to the success of the CNS Spectrums. I thank the departing members for their service over the years and I welcome the new editorial advisory board members and hope that their relationship with CNS Spectrums is mutually beneficial.

The new zeitgeist provides exciting opportunities for collaboration between basic and clinical researchers and between clinical researchers and clinicians. ${ }^{1,2}$ We live in exciting times with rapid progress in understanding basic brain functions, including apoptosis and neuroprotection, ${ }^{3,4}$ neurogenesis, ${ }^{5-7}$ neurocircuitry, ${ }^{8}$ neurophysiology, ${ }^{9}$ neuropsychiatric genetics, ${ }^{10}$ pharmacogenetics, ${ }^{11}$ along with a growing understanding of bi-directional gene environment ${ }^{12,13}$ and brain-mind relationships.

We also live in a time when the pharmaceutical and medical device industries face formidable challenges in finding new targets and new interventions to improve the lives of people with the full spectrum of neuropsychiatric disorders. The work is difficult. The investments are large and risky. To be successful in novel drug development, the field will require cooperation and collaboration between the industry (where most new treatments come from and where all treatments are manufactured), academia (which has been of interest to the media and governmental agencies), and the National Institutes of Health. Transparency (knowing about relation-

Dr. Nierenberg is professor of psychiatry at Harvard Medical School, co-director of the Bipolar Clinic and Research Program, and associate director of the Depression Clinical and Research Program at Massachusetts General Hospital (MGH) in Boston.

Faculty Disclosures: Dr. Nierenberg consulted to or served on the advisory boards of Abbott, Appliance Computing, Inc., Brain Cells, Inc., Bristol-Myers Squibb, Eli Lilly, EpiQ, Forest, GlaxoSmithKline, Janssen, Jazz, Merck, Novartis, Pamlab, Pfizer, PGx Health, Pharmaceutica, Schering-Plough, Sepracor, Shire, Somerset, Takeda, and Targacept; he has received research support from Cederroth, Cyberonics, Forest, Medtronics, NARSAD, the National Institute of Mental Health, Ortho-McNeil-Janssen, Pamlab, Pfizer, Shire, and the Stanley Foundation through the Broad Institute; he has received past support from Bristol-Myers Squibb, Cederroth, Eli Lilly, Forest, GlaxoSmithKline, Janssen, Lictwer Pharma, Pfizer, and Wyeth; he has received honoraria from the MGH Psychiatry Academy (MGHPA activities are supporled through Independent Medical Education grants from Astra Zeneca, Eli Lilly, and Janssen; he earns fees for editorial functions for CNS Spectrums through MBL Communications, Inc., and Psychiatric Annals through Slack, Inc.; he receives honoraria as a CME Executive Director for the Journal of Clinical Psychiatry through Physicians Postgraduate Press; he has been on the speaker's bureaus of Bristol-Myers Squibb, Cyberonics, Eli Lilly, Forest, GlaxoSmithKline, and Wyeth; he has received royalties from Cambridge University Press and Belvoir Publishing; he owns stock options in Appliance Computing, Inc.; and owns the copyrights to the Clinical Positive Affect Scale and the MGH Structured Clinical Interview for the Montgomery Asberg Depression Scale, exclusively licensed to the MGH Clinical Trials Network and Institute. 
ships between industry and academics) and disclosure of those relationships can help the readers of studies judge whether or not a "conflict of interest" exists. ${ }^{14,15}$ But having those relationships does not nullify or invalidate the research just because those relationships exist. ${ }^{16-18}$ It would be most prudent for readers to apply critical thinking before judging a potential conflict, to assess the content before dismissing evidence as tainted or overly biased, and to ask critical questions before coming to premature conclusions about the legitimacy of research or reviews. We need to avoid making premature assumptions about the relationship between academics' financial disclosures and whether or not they have a conflict. Conflict of interest (and bias) comes in many flavors beyond a financial relationship and covers the full spectrum of human motivation: desire for promotion, recognition, awards, and accolades; vindication for cherished ideas; power; and even competition with peers. ${ }^{19}$ All of the work conducted in academia and industry must be in the service of patients. The story neglected in the mainstream media, blogs, and books critical of academic medicine in general, and academic psychiatry in particular, is simply this: Most academic psychiatrists and neuroscientists are honest, hard working, dedicated people who are willing to take the risks and sacrifices necessary to advance the field. Paraphrasing comments Fred Goodwin, MD, made at the 2008 American Psychiatric Association Annual Meeting a convergence rather than a conflict of interest between academics and industry is needed and, indeed, required for innovation and progress. It is my hope that the journal can help to disseminate these innovations with integrity that is consistent with the highest ethical standards possible.

Ultimately, research and reviews published in CNS Spectrums are best read with mindfulness: Was the paper scholarly? Was the research design appropriate for the question? Was the research conducted well? Are the statistics reasonable? Are the results plausible? Does the discussion illuminate the findings? Does the paper add to the body of knowledge or integrate available knowledge in ways that are useful? Is the full spectrum of evidence that supports and refutes conclusions included or are key findings contrary to dearly held beliefs excluded? We owe thanks to the tireless volunteer reviewers who critically assess submissions to the journal. But as readers, we all have the responsibility to read the papers as carefully as the reviewers. Nothing less than the health of our patients is at stake.

In the spirit of true inquiry and advancing the field, CNS Spectrums welcomes papers that cover the full spectrum of psychiatric and neuropsychiatric issues. Critical reviews and informative clinical trials are especially welcome. Visit CNS Spectrums online at www.cnsspectrums.com, and please let me know how you think CNS Spectrums is doing. CNS

\section{REFERENCES}

1. Insel TR. Disruptive insights in psychiatry: transforming a clinical discipline. J Clin Invest. 2009;119:700-705.

2. Insel TR. Translating scientific opportunity into public health impact: a strategic plan for research on mental illness. Arch Gen Psychiatry. 2009:66:128-133.

3. Gould TD, Chen G, Manji HK. Mood stabilizer psychopharmacology. Clin Neurosci Res. 2002;2:193-212.

4. Marx CE, Yuan PX, Kilts JD, Madison RD, Shampine LJ, Manji HK. Neuroactive steroids, mood stabilizers, and neuroplasticity; alterations following lithium and changes in $\mathrm{Bcl}-2$ knockout mice. Int J Neuropsychopharmacol. 2008;11:547-552.

5. Eriksson PS, Perfilieva E, Bjork-Eriksson T, et al. Neurogenesis in the adult human hippocampus. Nat Med. 1998;4:1313-1317.

6. Zhao CM, Deng W, Gage FH. Mechanisms and functional implications of adult neurogenesis. Cell. 2008;132:645-660.

7. Sahay A, Hen R. Adult hippocampal neurogenesis in depression. Nat Neurosci. 2007:10:1110-1115.

8. Pezawas L, Meyer-Lindenberg A, Drabant EM, et al. 5-HTLPR polymorphism impacts human cingulate-amygdala interactions: a genetic susceptibility mechanism for depression. Nat Neurosci. 2005;8:828-834

9. Quiroz JA, Gray NA, Kato T, Manji HK. Mitochondrially mediated plasticity in the pathophysiology and treatment of bipolar disorder. Neuropsychopharmacology. 2008:33:2551-2565

10. Landis S, Insel TR. The "neuro" in neurogenetics. Science 2008;322:821-821.

11. Lin EG, Chen PS. Pharmacogenomics with antidepressants in the STAR*D study. Pharmacogenomics. 2008;9:935-946.

12. Caspi A, Sugden K, Moffitt TE, et al. Influence of life stress on depression: moderation by a polymorphism in the 5-HT gene. Science. 2003;301:386-389

13. Kendler KS, Baker JH. Genetic influences on measures of the environment: a systematic review. PsycholMed 2007:37:615-626.

14. DeAngelis CD. The influence of money on medical science. JAMA. 2006;296:996-998.

15. Angell M. Drug Companies \& Doctors: A Story of Corruption [New York Review of Books Web site]. January 15, 2009. Available at: http://www.nybooks.com/articles/22237. Accessed January 15, 2009

16. Duvall DG. Conflict of interest or ideological divide: the need for ongoing collaboration between physicians and industry. Curr Med Res Opin. 2006;22:1807-1812.

17. Stossel TP. Regulating academic-industrial research relationships-solving problems or stifling progress? N Engl J Med. 2005:353:1060-1065.

18. Stossel TP, Lee K. Has the hunt for conflicts of interest gone too far? BMJ. 2008:336:476-477.

19. Nierenberg AA. A counter proposal to manage financial conflicts of interest in academic psychiatry. Worid Psychiatry. 2007;6:34-36. 